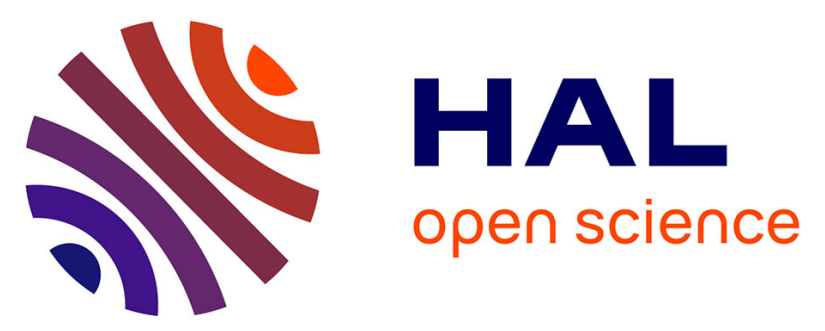

\title{
Life cycle assessment of in situ mariculture in the Mediterranean Sea for the production of bioactive compounds from the sponge Sarcotragus spinosulus
}

Paula Perez-Lopez, Fabio D Ledda, Angela D Bisio, Gumersindo D Feijoo, Erica D Perino, Roberto D Pronzato, Renata D Manconi, Maria Teresa

Moreira

\section{To cite this version:}

Paula Perez-Lopez, Fabio D Ledda, Angela D Bisio, Gumersindo D Feijoo, Erica D Perino, et al.. Life cycle assessment of in situ mariculture in the Mediterranean Sea for the production of bioactive compounds from the sponge Sarcotragus spinosulus. Journal of Cleaner Production, 2017, 142 (Part 4), pp.4356-4368. hal-01436090

\section{HAL Id: hal-01436090 https://hal.science/hal-01436090}

Submitted on 16 Jan 2017

HAL is a multi-disciplinary open access archive for the deposit and dissemination of scientific research documents, whether they are published or not. The documents may come from teaching and research institutions in France or abroad, or from public or private research centers.
L'archive ouverte pluridisciplinaire HAL, est destinée au dépôt et à la diffusion de documents scientifiques de niveau recherche, publiés ou non, émanant des établissements d'enseignement et de recherche français ou étrangers, des laboratoires publics ou privés. 


\section{Life cycle assessment of in situmariculture in the}

\section{Mediterranean Sea for the production of bioactive}

\section{compounds from thesponge Sarcotragusspinosulus}

Paula Pérez-López ${ }^{1,2 *}$, Fabio D. Ledda ${ }^{3,4,5}$, Angela Bisio ${ }^{6}$, Gumersindo Feijoo $^{1}$, Erica Perino $^{3}$, Roberto Pronzato ${ }^{3}$, Renata Manconi ${ }^{4}$, Maria Teresa Moreira ${ }^{1}$

${ }^{1}$ Department of Chemical Engineering, School of Engineering, University of Santiago de Compostela.15782 - Santiago de Compostela, Spain

${ }^{2}$ Current address: Centre Observation, Impacts, Energie (O.I.E.), MINES ParisTech, PSL Research University, CS 10207 rue Claude Daunesse, 06904 Sophia Antipolis Cedex, France

${ }^{3}$ Dipartimento di Scienzedella Terra, dell'Ambiente e della Vita (DISTAV), Università di Genova, Genova, Italy

${ }^{4}$ Dipartimento di Scienzedella Natura e del Territorio (DIPNET), Università di Sassari, Sassari, Italy

${ }^{5}$ Centre for Integrative Biology (CIBIO), University of Trento, 38123, Trento, Italy

${ }^{6}$ Dipartimento di Farmacia (DIFAR), Università di Genova, Genova, Italy

* Corresponding author: Tel.: +33 4971570 55; E-mail address:

paula.perez_lopez@mines-paristech.fr 


\begin{abstract}
Marine sponges are one of the most diverse invertebrates and show a great ability to produce valuable natural products with high biological activities. The main bottleneck for the commercial exploitation is the need of continuous biomass production in sufficient amount. In this study, the in situ cultivation of the sponge Sarcotragusspinosulus insea-based farming structures was evaluated according to the Life Cycle Assessment (LCA) standardized methodology. The results demonstrated that the cultivation aiming at the extraction of bioactive moleculeshad a more environmentally-friendly performancethanthe subsequent downstream processes, which were the main cause of the impact. Moreover, the simulation of alternative scenarios showed the possibility of achieving remarkable reductions of impact, as well as the effect of changes in key issues of the process: the effect of different approaches in the use of boats (exclusively used for the sea-based farming plants and the sponges collection or shared for other activities) as well as the influence of the survival rate.
\end{abstract}

KeywordsPrenylhydroquinones, Porifera, sustainable biomass production, sea-based farming,environmental LCA

\title{
1. Introduction
}

Marine sponges are one of the most diverse aquatic invertebrates due to the large number of species and the variety of morphological characteristics (Blunt et al., 2015, Pérez-López et al., 2014a). Although nearly 8000 different species have been identified, this number is estimated to represent only half of the total marine sponges (Pérez-López et al., 2014a; Thakur and Müller, 2004). According to Blunt et al. (2015), up to 7000 natural products have been isolated from marine sponges worldwide, an amount that increases annually. Some of the target molecules (e.g. halichondrin B, avarol, 
crambescidins) have shown high biological activities with potential applications in the pharmaceutical industry due to their anti-inflamatory, antitumor, immunosuppressive or antiviral properties, among others (Bergman et al., 2011; Bondu et al., 2012; Newman and Cragg, 2004; Sipkema et al., 2005a). Indeed, some drugs derived from sponges such as cytosine arabinoside Ara-C (chemically synthesized from nucleosides from the marine sponge Tethyacrypta) or eribulinmesylate (synthetic analog of halichondrin B, obtained from the marine sponge Halichondriaokadai)are already commercialized as anticancer agents(Beedessee et al., 2015; Dybdal-Hargreaves et al., 2015; Huyck et al., 2011). Other applications include the production of new biomaterials for nanotechnology (e.g. use of biosilica-producing enzymes) or fiber-optic communications (e.g. silicon skeleton of glass sponges with unique optical and mechanical properties) (Kulchin et al., 2009; Schippers et al., 2012).

The wider exploitation of bioactive compounds from marine origin and particularly from sponges is currently hampered by the lack of large-scale systems for the steady cultivation of the producer organisms (Murray et al., 2013). Sea-based farming (also known as in situ culture or "mariculture") of sponges has been proposed and successfully applied for species native to several habitats including the Mediterranean, Indo-Pacific and South Pacific regions(Duckworth, 2009; Osinga et al., 2010; Page et al., 2011; Pronzato and Manconi, 2008; Sipkema et al., 2005b). Despite the difficult control of culture conditions and the exposure to unfavorable climate phenomena, survival rates between $11 \%$ and $100 \%$, depending on the species, location and culture depth, have been reported(De Caralt et al., 2010; Duckworth, 2009; Osinga et al., 2010; Schippers et al., 2012). Growth rates found in literature show a remarkable variability and range from negative values (i.e. body size decrease) up to $2000 \%$ of the original size per year (Page et al., 2011; Pronzato and Manconi, 2008; Schippers et al., 2012). 
The start-up of anin situ sponge culture consists in the fragmentation of specimens collected from the wild habitat by cutting them into sponge explants. The explants are then placed on submerged supporting structures for growth(Pronzato and Manconi, 2008; Schippers et al., 2012). Duckworth (2009)provides a detailed description of available systems for the aquaculture of bath sponges as well as producers of bioactive metabolites with two main methods: farmed on ropes (Figure 1) or inside a mesh. Survival rates are usually higher for sponges farmed in mesh due to the protection provided by the structure, which avoids explant damage. However, this structure and the associated biofouling problems also reduce water flow and therefore nutrient availability, resulting in low growth rates compared to culture on ropes(Duckworth, 2009).

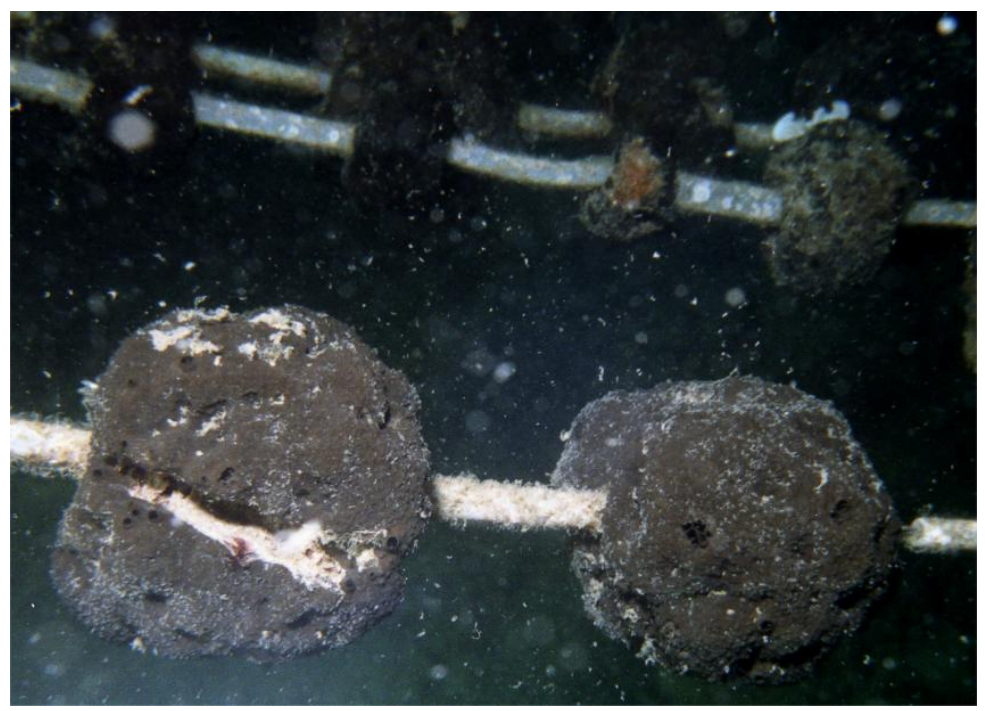

Figure 1.Close-up on a sponge farming structure showing several fragments (explants) of Sarcotragusspinosulus in nylon lines (ropes), Tramariglio Bay, Sardinia.

Since the final explant shape(i.e. growth form) is secondary for sponge aquaculture focused on the production of bioactive metabolites, a wider range of farming methods is possible. Among the proposed techniques, mesh arrays (consisting of mesh tubes divided into alternating pockets), nets stretched over metal frames, nylon ropes 
anchored to plastic frames and small plastic containers on horizontal lines are some of the most promising(Duckworth, 2009; Ledda et al., 2014; Page et al., 2005). Moreover, the specific goal of the cultivation allows the application of partial harvesting techniques. This option involves the collection of only a fraction of the sponge containing the target metabolite while the rest of the explant continues growing on the farming system (Duckworth, 2009).

Besides the high value of the produced metabolites, sponges grown in mariculture systems have the filtering ability that may allow bacterial and organic wasteremoval with efficiencies up to $80 \%$ for the bacterial load of the treated seawater(Ledda et al., 2014; Manconi et al., 1999; Page et al., 2011).

Due to all the advantages of culture on ropes (especially in terms of higher growth rates), the in situcultivation of the demosponge SarcotragusspinosulusSchmidt, 1862(Keratosa:Dictyoceratida:Irciniidae) sewn onto individual nylon ropes anchored to plastic frames is evaluated in this study. S. spinosulus is amassive horny sponge with a regular conulose,black to grey surface, and white to light brown interior. This photophilousdemosponge is commonly found in shallow waters, mainly in the Western Mediterranean coasts (Abed et al., 2011; Mercurio et al., 2013; Murray et al., 2013).

S. spinosulus(named Irciniaspinosula in previous works) is a natural producer of linear polyprenylhydroquinones (Cimino et al., 1972). This group of aromatic organic compounds exhibit moderate antibacterial, antiviral, anti-inflammatory and cytotoxic activities (Abed et al., 2011). Moreover, it comprises precursors of a new class of drugs regulating glutamatergic and cholinergic transmission in the mammalian central nervous system (Bisio et al., 2014). Therefore, the interest on the sponge biomass production lies in the potential therapeutic uses of the natural products that can be extracted from it, while avoiding the current supply problems due to the complexity and high costs of 
thesynthetic routes in multiple steps(Ling et al., 2002; Molinari et al., 2000; Ran et al., 2001).

Although the bio-based process for the production of polyprenylhydroquinones by sponges is intuitively expected to provide a more sustainable source of the biomolecules than an alternative synthetic route, the evaluation of the environmental performance by quantitative means is necessary to ensure its environmental merit(Von Blottnitz and Curran, 2007). Life cycle assessment (LCA) is one of the most widespread environmental management tools and is recommended by the European Commission as the best framework for the assessment of products (European Commission, 2003). It has been extensively applied for the evaluation of fisheries and aquaculture production systems (Hospido and Tyedmers, 2005; Vázquez-Rowe et al., 2010; Ziegler et al., in press). More recently, the cultivation of other marine organisms, such as microalgae and seaweed, and their products, including biofuels and bioactive compounds, have also been analyzed from an environmental perspective through LCA(Brentner et al., 2011; Collet et al., 2011; Lardon et al., 2009; Pérez-López et al., 2014b; 2016). In particular, LCA has already been used to assess the environmental performance of mariculture systems for seaweed cultivation (Aitken et al., 2014; Langlois et al., 2012; Taelman et al., 2015) and also for other sponge cultivation approaches, namely ex situ growth in closed aquaria (Pérez-López et al., 2014a). Therefore, LCA methodology was also selected in this study as the appropriate tool to evaluate the environmental sustainability ofthe novel experimental protocol for $S$. spinosulusculturing, consisting of the yearly harvest of sponge explants grown in mariculture systems followed by the solvent extraction of the bioactive prenylhydroquinone fraction. The LCA was performed according to ISO 14040 standard(ISO 14040, 2006). 


\section{Materials and methods}

\subsection{Goal and scope definition}

The goal of this work is to evaluate the environmental performance of $S$. spinosulusmaricultureon nylon ropes anchored to a plastic frame and the further extraction of prenylhydroquinones. For this purpose, an attributional LCA according to ISO 14040 standard was performed to the system, which was developed with the function of obtaining a bioactive fraction of prenylhydroquinones. Although many recent LCAs dealing with related systems (i.e. fish and seafood LCAs) focus on a single impact category, namely climate change (Ziegler et al.,in press),a multi-criteria approach was selected in this case to include other aspects that may also be relevant forS. Spinosulus process. The selection of impact categories is further discussed in section 2.3.

In order to be consistent with the scale of production of the system, $100 \mathrm{mg}$ of the produced bioactive compound was selected as the functional unit (FU), corresponding to one year of the sponge explantscultivation collected from the wild habitat in one farming structure. The performed LCA is based on a cradle-to-gate approach, including: i) installation of sea-based farming structures, ii) collection and transport of sponges from natural environment, iii) explants settling, iv) monitoring of cultured sponges, v) harvesting of sponge explants, vi) preparation of the sponge biomass for extraction and vii) solvent extraction of prenylhydroquinone fraction.

First, the environmental burdens of the initial scenario were quantified and the main hotspots were identified. In addition, the most relevant stages and parameters were analyzed by conducting sensitivity assessments that include alternative scenarios. The goal of these analyses was to identify the improvement actions with the highest potential to reduce the impact in as many of the evaluated categories as possible. 
The assessment is based on real data fromamariculture experimental system of $S$. spinosulusmaintained for over 20 years in the Mediterranean coasts (particularly in two sites, in the Ligurian and Sardinian Seas). The farming protocol (Figure 1) was developed by the ItalianDISTAV at the UniversitàdegliStudi di Genova and DIPNET at the UniversitàdegliStudi di Sassari, and finally tested for 3 years in the framework of the BAMMBO international PF7 project. The target species was cultured on sea-based farming systems consisting of structures built with low cost, reusable materials (i.e. nylon, polyvinylchloride, steel and polyethylene). The system exploited the natural ability of sponges to regenerate from small fragments. The farming systems were installed in shallow water coastal areas close to the natural habitat of donor sponges (Tramariglio Bay, 40 $35^{\prime} 33^{\prime \prime} \mathrm{N}, \quad 08^{\circ} 10^{\prime} 12^{\prime}$ 'E, north-western Sardinia, Western Mediterranean Sea). Since sponges are active and mainly unselective filter feeders, the cultivated S. spinosulusobtained the required nutrients from the surrounding water column, which containedparticulate and dissolved organic matter as well as microalgae and bacteria. Figure 2 depicts the seven stages of the experimental process that are included within the system boundaries in the environmental study:

- S1. Preparation and installation of sea-based farming structures: At the beginning of the cultivation, the farming structures were built and installed in the selected site. The structures consisted of nylon ropes with a diameter of 2-5 $\mathrm{mm}$ (15 m nylon per structure) fastened to $1.5 \mathrm{~m}$ wide polyvinylchloride (PVC) square frames (6 m pipe with 4 annular connections), with polyethylene (LDPE) spacers of $1 \mathrm{~cm}$ in diameter to separate the specimens (15 $\mathrm{m}$ per structure). Each square frame supported 10 nylon lines with 10 sponge fragments each, so 100 sponge explants were cultured in each frame. A total of 300 sponge explants were transplanted in three farming structures. The settlement of these structures 
involved the use of an inflatable boat and SCUBA equipment for $2 \mathrm{~h}$. As an average, the same structures could be maintained in a farming site for at least 15 years.

- S2. Collection of sponge explants from natural habitat: Specimens for explantssettling in the mariculture structures were harvested in the natural habitat. In order to minimize ecological damage, only a fraction of each specimen was collected by cutting approximately $50 \%$ of total volume of the donor sponge. Due to the regeneration capacity, the remaining donor sponge was able to restore the damaged body portion and persist in its habitat.

The harvest of wild sponge explants was only needed to start the sponge culture and once each three yearsin subsequent phases of farming expansion. The sponge growth was sufficient to supply new explants (by cloning) for other cycles within the system life span, as well as the biomass required to extract the bioactive compound. For the collection and transport of sponges close to the farming site, both the boat and SCUBA equipment of S1 were used. For the cultivation in three farming structures, $10 \mathrm{~kg}$ of sponge biomass (wet weight) was collected at the beginning of each cultivation cycle (3 years).

- S3. Preparation of explants and sponge settling: The collected specimens (10 kg every 3 years for 3 -module system) were fragmented with scalpels to obtain explants ca. $30-50 \mathrm{~cm}^{3}$ each. Before settling, the wet weight of each explant was measured with a portable balance, and the volume was determined either by volume displacement or by image analysis of photographs (ImageJ). The explants were then settled onto the farming structures and maintained for growth. 
- S4. Monitoring and maintenance of farming system: The mariculture systems were periodically monitored to assess the sponge explants survival and growth rates. Each explant was monitored by direct measures and photographs. The step was conducted once every three months. Since the structures were located in a shallow water site close to the shore, the use of boat was not required in the baseline scenario.

- S5. Sponge harvesting and transport to facility for extraction: Once per year, sponges were harvested and transported by passenger car to the laboratory where a solvent extraction was performed. In this period, an approximate growth of $100 \%$ was observed for the surviving specimens. A survival rate of $80 \%$ was considered for the baseline scenario, according to the results reported by Ledda et al. $(2009 ; 2014)$.

- S6. Preparation of crude extract: The harvested biomass was rinsed with water and cut into small slices. The fragments were grinded and freeze-dried for extraction. During the process, $2 \mathrm{~L}$ of tap water and $2 \mathrm{~L}$ of distilled water per gram of freeze-dried sample were required. For the preparation of crude extract, 1 Lmethanoltogether with 0.5 Ln-hexane, chloroform and carbon tetrachloride per gram of sponge were used. The extraction was conducted at room temperature and the extract was filtered and concentrated under reduced pressure.

- S7. Extraction of prenylhydroquinones: The crude extract from the previous stage was dissolved in a mixture of methanol and water $(9: 1 \mathrm{v} / \mathrm{v})$, and partitioned against $1 \mathrm{~L}$-hexane. The water content of the methanolic fraction was adjusted to $20 \%$ and partitioned against chloroform. The extract was concentrated to remove the solvent and obtain the prenylhydroquinone fraction. 


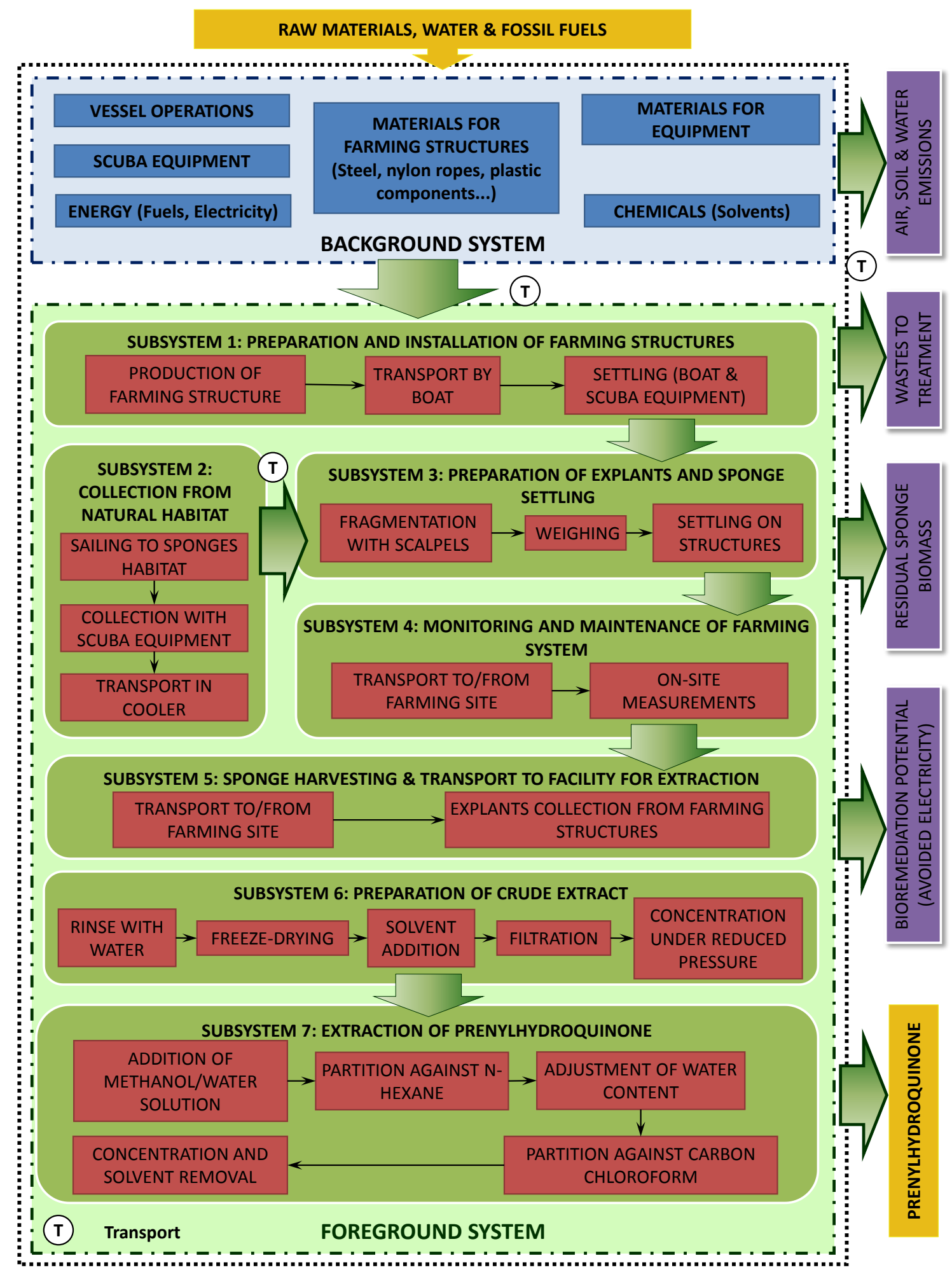

Figure2.Process chain and system boundaries of the in situmariculture of $S$.

spinosulusfor the production of prenylhydroquinones. 


\subsection{Life cycle inventory, data quality and assumptions}

The life cycle inventory (LCI) data for the foreground system (i.e. raw materials for farming structures, chemicals, transport distances, fuel and electricity consumption) consisted of average data obtained by on-site measurements at several farming sites located in the Ligurian and Sardinian Seas and described in detail by Ledda et al. (2014). The farming sites have been operating for about 15 years, so the measurements that allow quantifying the inventory data for the foreground system are considered representative of the sponge cultivation for this Mediterranean area. Air emissions, mainlyfrom the combustion of the boat engine, and water emissions from the different stages, were assumed to be directly discharged to the environment. Table 1 shows the global inventory for the baseline scenario. 
Table 1.Global inventory for mariculture and prenylhydroquinone extraction from the sponge $S$. spinosulus ( $\mathrm{FU}=100 \mathrm{mg}$ bioactive fraction)

\section{INPUTS from TECHNOSPHERE}

\section{Materials}

S1. Preparation and installation of farming structures

Synthetic rubber

$1.96 \mathrm{~kg}$ Nylon (farming $37.50 \mathrm{~g}$

Steel (engine and scuba equip.)

$1.21 \mathrm{~kg} \quad$ PVC (farming structures)

Lubricant oil

$2.32 \mathrm{~g}$

Steel (farming structures)

$18.75 \mathrm{~g}$

Compressed air (200 bar)

$0.10 \mathrm{~kg}$

LDPE (farming structures)

Water (maintenance) $3.08 \mathrm{t}$

S2. Collection of sponge explants from natural habitat

Synthetic rubber

$9.80 \mathrm{~kg}$ Compressed air (200 bar)

$0.73 \mathrm{~kg}$

Steel

$6.05 \mathrm{~kg}$

Water (maintenance)

Lubricant oil

$11.49 \mathrm{~g}$

Polypropylene (PP)

$0.55 \mathrm{~kg}$

S3. Preparation of explants and sponge seeding

Steel

$7.44 \mathrm{~g} \quad$ Electric battery

$0.36 \mathrm{~g}$

S4. Monitoring and maintenance of farming system

Steel

$27.50 \mathrm{~g} \quad$ Electric battery

$1.44 \mathrm{~g}$

S5. Preparation of crude extract

Tap water

$500 \mathrm{~kg} \quad \mathrm{~N}$-hexane

$81.85 \mathrm{~kg}$

Distilled water

$500 \mathrm{~kg}$ Chloroform

$186.25 \mathrm{~kg}$

Methanol

$198 \mathrm{~kg}$

Carbon tetrachloride

$198.75 \mathrm{~kg}$

Steel

$0.12 \mathrm{~kg}$

Glass

$0.05 \mathrm{~kg}$

\section{Energy}

S1. Preparation and installation of farming structures

S5. Preparation of crude extract

Petrol

$0.77 \mathrm{~kg}$

Electricity for freezedrying

$7.20 \mathrm{kWh}$

S2. Collection of sponge explants from natural habitat

Electricity for solvent $\quad 39.06 \mathrm{kWh}$

Petrol

$3.86 \mathrm{~kg}$ evaporation

\section{Transport}

Truck, 3.5-7.5 t (materials)

$3.58 \mathrm{tkm}$

Truck, 3.5-7.5 t

(chemicals)

$122.2 \mathrm{tkm}$

Passenger car (S1, S2, S4, S5)

197.31 tkm Truck, 3.5-7.5 t (waste)

$0.99 \mathrm{tkm}$ 
Table 1.Global inventory for mariculture and prenylhydroquinone extraction from the sponge $S$. spinosulus (FU=100 mg bioactive fraction) (Cont.)

\begin{tabular}{|c|c|c|c|}
\hline \multicolumn{4}{|c|}{ INPUTS from ENVIRONMENT } \\
\hline \multicolumn{4}{|l|}{ Materials } \\
\hline Sponge biomass (wet weight) & $1.04 \mathrm{~kg}$ & Seawater & $5.21 \mathrm{~L}$ \\
\hline Occupation, sea and ocean & $2.11 \mathrm{~m} 2 \mathrm{a}$ & & \\
\hline \multicolumn{4}{|c|}{ OUTPUTS to TECHNOSPHERE } \\
\hline \multicolumn{4}{|l|}{ Product } \\
\hline Prenylhydroquinone & $100 \mathrm{mg}$ & & \\
\hline \multicolumn{4}{|l|}{ Avoided product } \\
\hline Electricity (UV filter) & $84.37 \mathrm{~kW}$ & & \\
\hline \multicolumn{4}{|l|}{ Waste treatment } \\
\hline \multicolumn{4}{|c|}{ S1. Preparation and installation of farming structures } \\
\hline Synthetic rubber & $1.96 \mathrm{~kg}$ & Steel & $1.21 \mathrm{~kg}$ \\
\hline \multicolumn{4}{|c|}{ S2. Collection of sponge explants from natural habitat } \\
\hline Synthetic rubber & $9.80 \mathrm{~kg}$ & Steel & $6.05 \mathrm{~kg}$ \\
\hline PP & $0.55 \mathrm{~kg}$ & & \\
\hline \multicolumn{4}{|c|}{ S3. Preparation of explants and sponge seeding } \\
\hline Steel & $7.44 \mathrm{~g}$ & Electric battery & $0.36 \mathrm{~g}$ \\
\hline \multicolumn{4}{|c|}{ S4. Monitoring and maintenance of farming system } \\
\hline Steel & $27.50 \mathrm{~g}$ & Electric battery & $1.44 \mathrm{~g}$ \\
\hline \multicolumn{4}{|l|}{ S5. Annual harvesting } \\
\hline Nylon & $37.50 \mathrm{~g}$ & LDPE & $18.75 \mathrm{~g}$ \\
\hline PVC & $37.50 \mathrm{~g}$ & Steel & $18.75 \mathrm{~g}$ \\
\hline \multicolumn{4}{|l|}{ S6. Preparation of crude extract } \\
\hline Steel & $0.12 \mathrm{~kg}$ & Glass & $0.05 \mathrm{~kg}$ \\
\hline
\end{tabular}


Table 1.Global inventory for mariculture and prenylhydroquinone extraction from the sponge $S$. spinosulus (FU=100 mg bioactive fraction) (Cont.)

\begin{tabular}{|c|c|c|c|}
\hline \multicolumn{4}{|c|}{ OUTPUTS to ENVIRONMENT } \\
\hline \multicolumn{4}{|l|}{ Air emissions } \\
\hline \multicolumn{4}{|c|}{ S1. Preparation and installation of farming } \\
\hline \multicolumn{4}{|c|}{ structures (from vessel operations) } \\
\hline Carbon dioxide $\left(\mathrm{CO}_{2}\right)$ & $2.454 \mathrm{~kg}$ & Methane $\left(\mathrm{CH}_{4}\right)$ & $0.139 \mathrm{~g}$ \\
\hline Sulfur dioxide $\left(\mathrm{SO}_{2}\right)$ & $0.002 \mathrm{~kg}$ & Nitrogen oxides (NOx) & $0.031 \mathrm{~kg}$ \\
\hline \multirow{2}{*}{$\begin{array}{l}\text { Non-methane volatile organic } \\
\text { compounds (NMVOC) }\end{array}$} & $0.039 \mathrm{~kg}$ & Carbon monoxide $(\mathrm{CO})$ & $0.006 \mathrm{~kg}$ \\
\hline & & $\begin{array}{l}\text { Particulates }<10 \mu \mathrm{m} \\
\left(\mathrm{PM}_{10}\right)\end{array}$ & $0.002 \mathrm{~kg}$ \\
\hline \multicolumn{4}{|c|}{$\begin{array}{l}\text { S2. Collection of sponge explants from natural } \\
\text { habitat (from vessel operations) }\end{array}$} \\
\hline $\mathrm{CO}_{2}$ & $12.270 \mathrm{~kg}$ & $\mathrm{CH}_{4}$ & $0.695 \mathrm{~g}$ \\
\hline $\mathrm{SO}_{2}$ & $0.008 \mathrm{~kg}$ & NOx & $0.153 \mathrm{~kg}$ \\
\hline \multirow[t]{2}{*}{ NMVOC } & $0.193 \mathrm{~kg}$ & $\mathrm{CO}$ & $0.029 \mathrm{~kg}$ \\
\hline & & $\mathrm{PM}_{10}$ & $0.012 \mathrm{~kg}$ \\
\hline \multicolumn{4}{|l|}{ Water emissions } \\
\hline \multicolumn{4}{|c|}{$\begin{array}{l}\text { S1. Preparation and installation of farming } \\
\text { structures (from vessel maintenance - washing) }\end{array}$} \\
\hline Wastewater & $3.08 \mathrm{~m}^{3}$ & & \\
\hline \multicolumn{4}{|c|}{$\begin{array}{l}\text { S2. Collection of sponge explants from natural } \\
\text { habitat (from vessel maintenance - washing) }\end{array}$} \\
\hline Wastewater & $15.42 \mathrm{~m}^{3}$ & & \\
\hline \multicolumn{4}{|l|}{ S6. Preparation of crude extracts } \\
\hline Methanol & $250 \mathrm{~L}$ & Carbon tetrachloride & $125 \mathrm{~L}$ \\
\hline N-hexane & $125 \mathrm{~L}$ & Wastewater & $1000 \mathrm{~L}$ \\
\hline Chloroform & $125 \mathrm{~L}$ & & \\
\hline \multicolumn{4}{|c|}{ S7. Extraction of prenylhydroquinone } \\
\hline Methanol & $15 \mathrm{~L}$ & Chloroform & $1 \mathrm{~L}$ \\
\hline N-hexane & $1 \mathrm{~L}$ & Wastewater & $3 \mathrm{~L}$ \\
\hline
\end{tabular}

The inputs from the background system include the production of the different materials for the farming structures (i.e. nylon ropes, PVC, LDPE and steel snap hooks), the vessel and SCUBA equipment used for the preparation of farming structures and the sponge collection from the wild habitat, as well as the different chemicals required for 
the extraction and the materials for the equipment (e.g. freeze-dryer, solvent evaporator). They were inventoried according to Ecoinvent v2.2 database. An average life span of 15 years was estimated for the farming structures. For the equipment, average weight and life span were estimated according to manufacturers' specifications. In the case of vessel operations, the emissions from fuel combustion were determined as shown in the EMEP/EEA air pollutant emission inventory guidebook (EMEP/EEA, 2009). Marine lubricant oil needed for the maintenance of the boat engine was inventoried according to Vázquez-Rowe et al. (2010). No other chemicals were consumed, since the model vessel was an inflatable boat that required no periodic addition of paint or anti-fouling. Water consumption for the boat washing was included in the LCI. The calculated amount of synthetic rubber (assumed for the hull) and steel required for the engine of the boat were increased by $25 \%$ and $50 \%$ respectively, to account for repair and maintenance activities of the boat (Hospido and Tyedmers, 2005). A life span of 10 years was estimated, according to the manufacturer's specifications. For the baseline scenario, the boat was considered to be exclusively used for tasks related to the evaluated process.

The background system also provides the energy used in the different production and extraction stages as well as waste treatment. Solid wastes were assumed to be disposed of in sanitary or inert landfills, except for synthetic rubber, which was sent to incineration according to Ecoinventprocesses. The consideredtransport distanceswere $180 \mathrm{~km}$ for chemicals and equipment and $50 \mathrm{~km}$ for waste to disposal site. Inventory data for all those background processes were taken from the Ecoinvent database, as summarized in Table 2. 
Table 2.Summary of data sources for background system

\begin{tabular}{|c|c|c|}
\hline Involved process & Raw material & Reference \\
\hline \multirow{2}{*}{ Energy } & Diesel & $\begin{array}{l}\text { Ecoinvent database (Jungbluth, } \\
\text { 2007) }\end{array}$ \\
\hline & $\begin{array}{l}\text { Electricity (from the } \\
\text { Italian grid) }\end{array}$ & $\begin{array}{l}\text { Ecoinventdatabase(Dones et al., } \\
\text { 2007) }\end{array}$ \\
\hline \multirow{7}{*}{ Materials } & Steel & $\begin{array}{l}\text { Ecoinventdatabase(Classen et al., } \\
\text { 2007) }\end{array}$ \\
\hline & Synthetic rubber & \multirow{5}{*}{ Ecoinvent database (Hischier, 2007) } \\
\hline & Nylon 6 & \\
\hline & PVC & \\
\hline & LDP & \\
\hline & $\mathrm{PP}$ & \\
\hline & Electric battery & $\begin{array}{l}\text { Ecoinventdatabase(Hischier et al., } \\
\text { 2007) }\end{array}$ \\
\hline \multirow{4}{*}{ Chemicals } & Marine lubricant oil & Vázquez-Rowe et al. (2010) \\
\hline & $\begin{array}{l}\text { Methanol } \\
\text { Chloroform }\end{array}$ & \multirow[t]{2}{*}{$\begin{array}{l}\text { Ecoinventdatabase(Althaus et al., } \\
\text { 2007) }\end{array}$} \\
\hline & Carbon tetrachloride & \\
\hline & N-hexane & $\begin{array}{l}\text { Ecoinvent database (Jungbluth, } \\
\text { 2007) }\end{array}$ \\
\hline $\begin{array}{l}\text { Air for scuba } \\
\text { equipment }\end{array}$ & Compressed air & $\begin{array}{l}\text { Ecoinvent database (Steiner and } \\
\text { Frischknecht, 2007) }\end{array}$ \\
\hline Water supply & $\begin{array}{l}\text { Tap water } \\
\text { Distilled water }\end{array}$ & $\begin{array}{l}\text { Ecoinventdatabase(Althaus et al., } \\
\text { 2007) }\end{array}$ \\
\hline Waste treatment & $\begin{array}{l}\text { Inert landfill } \\
\text { Sanitary landfill } \\
\text { Municipal } \\
\text { incineration }\end{array}$ & Ecoinvent database (Doka, 2007) \\
\hline
\end{tabular}

\section{Allocation procedures}

In this case, the process aims the production of only one bioactive fraction: prenylhydroquinone. Thus, no allocation procedure was required and all the environmental burdens were associated with prenylhydroquinone (100 $\mathrm{mg}$ per year of cultivation in a single sea-based farming structure). Although no additional 
biomolecules were isolated from S. spinosulus, the residual sponge biomass after prenylhydroquinone extraction might contain other valuable products. Further extraction could allow the recovery of additional biomolecules that would lead to the reduction of the relative impact for each fraction and hence to improve the environmental profile of the process.

The analyzed sponge mariculture system showed the ability to act as a natural filter for the treatment of large volumes of water with high organic and bacterial load (Ledda, 2009; 2014).According to the literature (Bergquist, 1978), the sponge pumping rate is highly variable depending on physiology and environmental conditions. Thus, the resulting values for several investigated species (e.g. Agelasoroides,Irciniavariabilis,Spongia officinalis,Verongialacunosa) are in a very wide range, from less than $1 \mathrm{~L}$ of filtered water per hour per $\mathrm{L}$ of sponge volume up to $500 \mathrm{~L} \cdot \mathrm{h}^{-1} \cdot \mathrm{L}^{-1}($ Gerrodette and Flechsing, 1979; Ledda et al., 2014; Stabili et al., 2006). Although the pumping rate for the evaluated farming plant was not measured, the bioremediation potential of the system is modeledaccording to an intermediate pumping rate of $200 \mathrm{~L} \cdot \mathrm{h}^{-1} \cdot \mathrm{L}^{-1}$. In this scenario, $15 \mathrm{~L}$ of $S$. spinosulushosted in the Tramariglio plant could filter approximately $24,000 \mathrm{~m}^{3}$ per year (based on a $100 \%$ growth and $80 \%$ survival rate per specimen), which would involve an electricity consumption in the lab of about270 $\mathrm{kWh} \cdot \mathrm{year}^{-1}$ by an UV (ultraviolet) sterilizer (acommon technology for water purification). This environmental benefit was taken into account in the LCA study by applying a system expansion approach. Thus, the UV sterilizer electricity consumption with an equivalent function was considered as "avoided product" and the corresponding environmental burdens were subtracted from the total impact of the process. 


\subsection{Environmental impact assessment}

The environmental profile for the production of prenylhydroquinone from S. spinosulus cultured in situ was assessed by performing the classification and characterization stages of the LCA methodology (ISO 14040, 2006). The characterization factors reported by the Centre of Environmental Science of Leiden University (CML 2001 method) were used (Guinée et al., 2002). Although more recent impact assessment methods have been developed (European Commission and Joint Research Centre, 2012; Goedkoop et al., 2013a), CML impact categories were selected in this case to allow direct comparisons with previous LCA studies on biologically active compounds from marine origin and microalgal biofuels(Collet et al., 2011; Lardon et al., 2009; PérezLópez et al., 2014a; b;2016).

The impact potentials evaluated according to the CML method were: abiotic depletion (ADP), acidification (AP), eutrophication (EP), global warming (GWP), ozone layer depletion (ODP), human toxicity (HTP), freshwater aquatic ecotoxicity (FEP), marine aquatic ecotoxicity (MEP), terrestrial ecotoxicity (TEP) and photochemical oxidants formation (POFP). Additionally, ecological footprint method was used to evaluate resource depletion in terms of biologically productive land and water (Huijbregts et al., 2008). This impact assessment method includes indicators for direct land occupation (LDirect), land occupation to compensate for $\mathrm{CO}_{2}$ emissions $\left(\mathrm{LCO}_{2}\right.$, that is, forest area needed for sequestration) and land occupation due to nuclear energy demand (LNuclear). It is important to remark that the indicator of direct land occupation includes specific characterization factors for sea and ocean occupation, so it allows evaluating the effect of the sea-based farming structures described in this paper. In this 
study, the characterization factor for sea land occupation was considered as if the mariculture system occupied the sea area completely. This approach uses the highest characterization factor possible and therefore reflects a "worst-case scenario". Recent approaches, such as the method proposed by Taelman et al. (2015), may allow calculating a more accurate occupation factor that reflects the open space within the system. Taelman's method takes into account variations within growing and fallow periods as well as those due to the harvest of seed biomass. For the purpose of this study, the first approach was considered suitabledue to the reasons presented in the results section. In line with this approach, the harvest of seed biomass was not accounted for.

The impact categories were selected with the aim of providing a multi-criteria analysis based on a comprehensive range of environmental issues. The chosen indicators, also included in other impact assessment methods such as ReCiPe, were oriented to the measurement of resource depletion (e.g. ADP, LDirect, $\mathrm{LCO}_{2}$, LNuclear), impacts in ecosystems (e.g. AP, EP, GWP, FEP, MEP, TEP) and impacts in human health (GWP, ODP, HTP, POFP) (Goedkoop et al., 2013a; Guinée et al., 2002). The software SimaPro 8.0.2 was used for the computational implementation of the inventories (Goedkoop et al., 2013b).

\section{Results}

The characterization results for the production of prenylhydroquinones by the sponge $S$. spinosulus in the baseline scenario are shown in Table $\mathbf{3}$ and split into the stages and processes depicted in Figure 3. 
Table 3. Environmental impact assessment results (characterization step) associated with the production of $100 \mathrm{mg}$ prenylhydroquinones by S. spinosulus.

\begin{tabular}{|c|c|c|c|c|c|c|c|c|c|c|}
\hline $\begin{array}{l}\text { Impact } \\
\text { category }\end{array}$ & Unit & S1 & S2 & S3 & S4 & S5 & S7 & \multicolumn{2}{|c|}{ Bioremediation } & Total \\
\hline ADP & $\mathrm{kg} \mathrm{Sb}$ eq & 0.129 & 0.582 & 0.000 & 0.181 & 0.045 & 12.000 & 0.270 & -0.383 & 12.824 \\
\hline AP & $\mathrm{kg} \mathrm{SO}_{2} \mathrm{eq}$ & 0.062 & 0.277 & 0.000 & 0.081 & 0.020 & 4.808 & 0.034 & -0.271 & 5.012 \\
\hline $\mathrm{EP}$ & $\mathrm{kg} \mathrm{PO}_{4}{ }^{-3} \mathrm{eq}$ & 0.022 & 0.094 & 0.000 & 0.021 & 0.006 & 1.286 & 0.013 & -0.065 & 1.377 \\
\hline GWP & $\mathrm{kg} \mathrm{CO}_{2} \mathrm{eq}$ & 18.742 & 85.310 & 0.016 & 26.618 & 6.659 & 1373.549 & 16.615 & -53.962 & 1473 \\
\hline ODP & kg CFC-11eq & 0.000 & 0.000 & 0.000 & 0.000 & 0.000 & 0.224 & 0.002 & 0.000 & 0.226 \\
\hline HTP & kg 1,4-DBeq & 10.729 & 18.779 & 0.055 & 9.752 & 2.432 & 46316 & 21.588 & -12.766 & 46366 \\
\hline FEP & kg 1,4-DBeq & 4.300 & 18.681 & 0.019 & 3.222 & 0.992 & 228.892 & 2.280 & -9.146 & 249 \\
\hline MEP & kg 1,4-DBeq & 2.568 & 11.201 & 0.010 & 2.387 & 0.692 & 353.917 & 1.415 & -6.828 & 365 \\
\hline TEP & kg 1,4-DBeq & 0.001 & 0.011 & 0.000 & 0.001 & 0.000 & 0.253 & 0.001 & -0.003 & 0.265 \\
\hline POFP & $\mathrm{kg} \mathrm{C}_{2} \mathrm{H}_{4} \mathrm{eq}$ & 0.003 & 0.013 & 0.000 & 0.011 & 0.003 & 0.419 & 0.005 & -0.011 & 0.443 \\
\hline LDirect & $\mathrm{m} 2 \mathrm{a}$ & 1.818 & 4.604 & 0.001 & 2.200 & 0.551 & 26.548 & 0.322 & -0.969 & 35.075 \\
\hline $\mathrm{LCO} 2$ & $\mathrm{~m} 2 \mathrm{a}$ & 51.828 & 226.58 & 0.056 & 67.409 & 16.851 & 2092.06 & 23.890 & -137.321 & 2341.361 \\
\hline LNuclear & $\mathrm{m} 2 \mathrm{a}$ & 4.460 & 22.656 & 0.003 & 10.518 & 2.627 & 687.536 & 2.452 & -18.946 & 711.307 \\
\hline
\end{tabular}


a) Relative contributions of prenylhydroquinones from $S$. spinosulus per stage

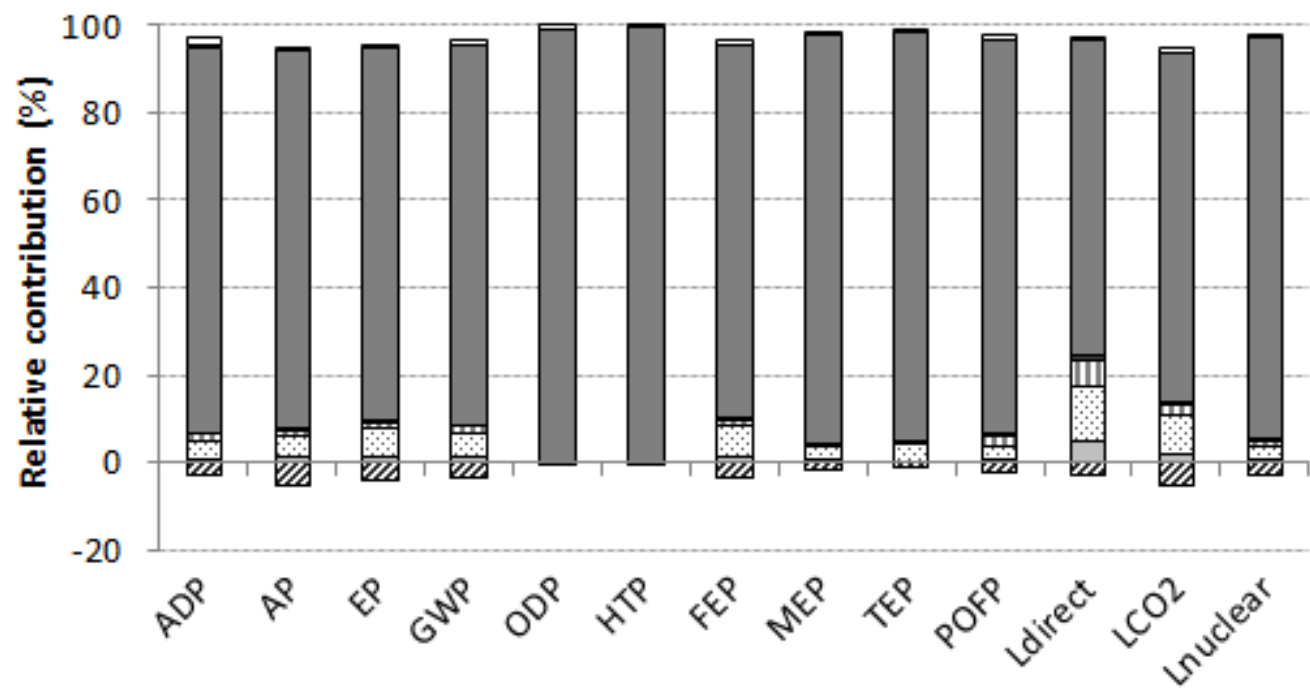

$\square$ S1. Preparation of farming structures

- $\$ 3$. Sponge seeding

ES5. Annual harvesting

$\square$ S7. Extraction of prenylhydroquinone
연. Collection from natural habitat

口S4. Monitoring and maintenance

$\square$ S6. Preparation of crude extract

$\square$ Bioremediation (bacterial removal)

b) Relative contributions of prenylhydroquinone from $S$. spinosulus per involved process

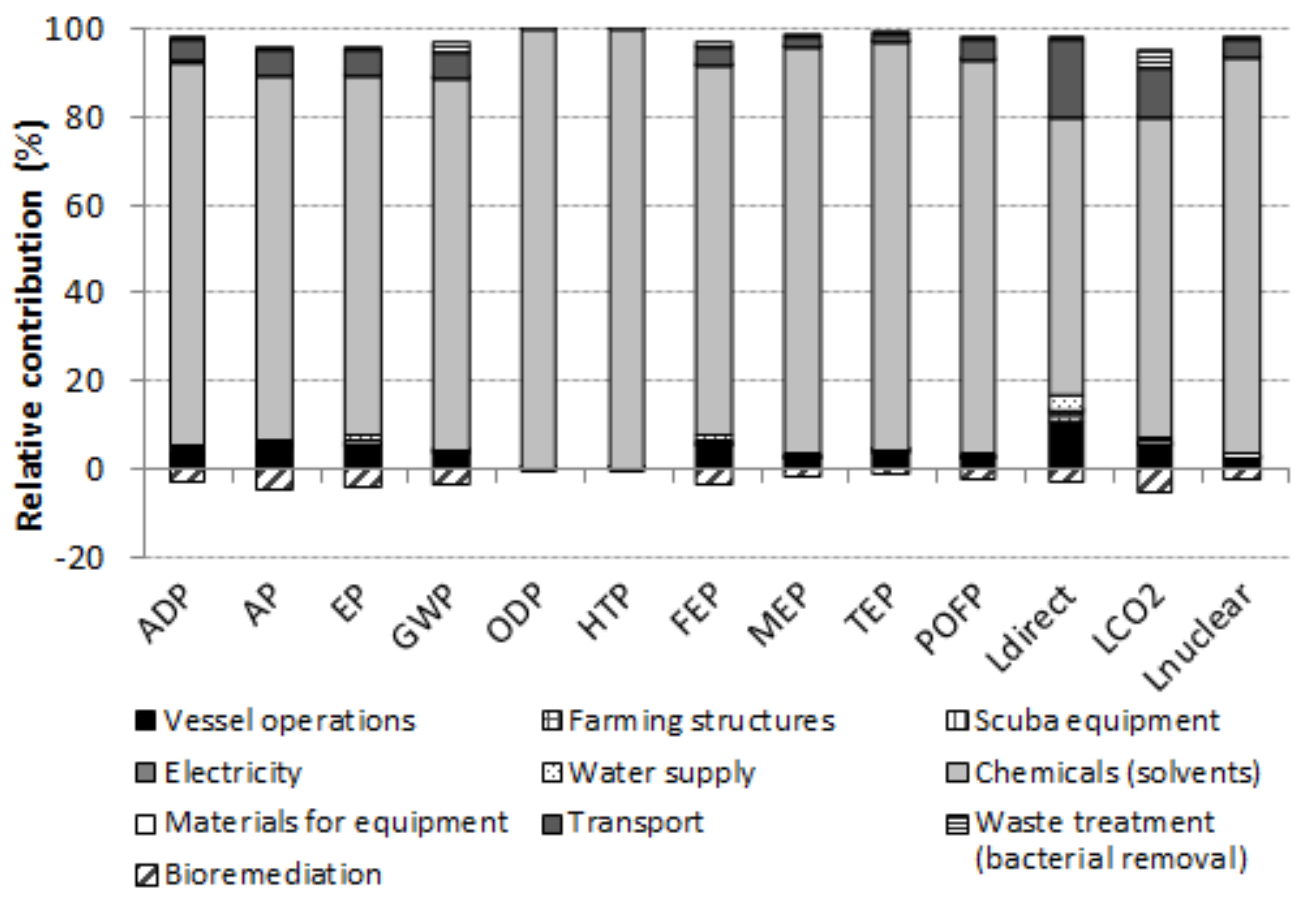

Figure 3.Relative contributions of the production of prenylhydroquinones by $S$.

spinosulusin sea-based farming structuresto each impact category per a) stage and b) involved process. 
According to the results, the preparation of the crude extract (S6) is the main contributor to the environmental burdens derived from the production of prenylhydroquinones from S. spinosulus grown in situ in sea-based farming structures. The contributions range between $85 \%$ and $99 \%$ for all categories. Among the secondary stages, only the relative impact of the collection of specimens from the natural habitat (S2) exceeds $5 \%$ in five of the evaluated categories: EP, GWP,FEP, LDirect and $\mathrm{LCO}_{2}$. Other stages such as the preparation and installation of the farming structures (S1) or the monitoring and maintenance of the mariculture system (S4) have marginal contributions of approximately $1-2 \%$ in most impact categories.

Regarding the involved processes, the production of chemicals used as solvents is associated with the largest impacts of the whole process. It involves between $81 \%$ and $99 \%$ of the total impact and is mainly associated with S6. The solvents consumed in S6 are responsible for up to $98 \%$ of these environmental burdens for all the categories (especially chloroform, followed by carbon tetrachloride and methanol), whereas the solvents for the extraction of prenylhydroquinone fraction from the crude extract (S7) constitute less than $2 \%$ of the total impact of chemicals.

The materials and emissions associated with the "vessel operation" and the emissions from transport are the only secondary activities with contributions above $5 \%$ in some categories, includingAP, EP, GWP,FEP and land occupation categories (LDirect and $\mathrm{LCO}_{2}$ ). Other processes such as the production of electricity for the downstream processing (mainly the preparation of the crude extract), the tap and distilled water required for the process or the production of materials for the SCUBA and lab equipment have contributions below $1 \%$ in nearly all categories. 
An important remark associated with resource depletion in terms of biologically productive land and water is that land occupation associated with the cultivation system installed in the sea has a limited effect compared to the total LDirect of the process, with a contribution of $2 \%$. It should be noticed that this contribution corresponds to the "worst-case scenario" approach. The characterization factor used to calculate sea occupation is based on the assumption that the mariculture system occupy the sea area completely and does not take into account the open space within the system. Thus, the contribution of S1 to LDirect is expected to decrease when applying a more accurate model, such as the method of Taelman et al. (2015). Due to the low relative contribution of this subsystem, the application of more accurate and complex characterization methods that may involve lower characterization factors for sea occupation is not expected to have a significant impact on final recommendations and conclusions. Hence, the original ecological footprint method was preferred in this study for simplicity.

Regarding the bioremediation potential of sponges (associated with the filtering capacity), the benefits linked to the bacterial and organic removal capacity are lower than $5 \%$ of the total environmental impact for all the evaluated categories.

\section{Discussion}

While several LCA studies dealing with the production of valuable metabolites from algae are available(Pérez-López et al., 2014b; 2016), sponge biomass production in mariculture systems to obtain high value biomolecules has only been evaluated from an economic point of view (Pronzato and Manconi, 2008; Sipkema et al., 2005b). Although no environmental analyses of other in situ cultivation systems for sponges are available, the results of the current work are in line with the findings of the economic 
evaluation, which already pointed out the relative importance of downstream processing. Thus, according to Sipkema et al. (2005b), the isolation and purification stages to obtain biocompounds from maricultured sponges are associated with $70-90 \%$ of the total variable costs of the process. The results are also in accordance with previous LCA studies on bioactive compounds from marine sponges that were cultivated in ex situ closed systems. Indeed, Pérez-López et al. (2014a) already identified the production of chemicals related to extraction and purification stage as one of the key hotspots for the isolation of antitumor compounds (namely crambescin A1 and crambescidin 816) from the encrusting sponge Crambecrambe. However, the relative contribution of chemicals for $S$. spinosulus is slightly higher than in the case of $C$. crambefor two main reasons:

1) The cultivation in closed indoor systems required relatively high electricity consumption associated with the illumination of the aquariums that is not needed in the case of ex situ systems. Thus, the increase of the relative contribution of the electricity to the total environmental impact involves a moderate reduction of the contribution of chemicals (below 90\% in the analyzed impact categories).

2) The use of an optimized purification strategy allowed the minimization of solvent requirements, and contributed to the reduction of the environmental impact of chemicals.

The benefit of in situ cultivation in terms of avoiding electricity consumption during the growth phase is also observed when comparing the environmental profile of $S$. spinosulusprocess for the production of prenylhydroquinones to other LCA studies on bioactive compounds in the field of marine biotechnology (Pérez-López et al., 2014a; 2016). Opposite to these processes, which presented remarkable electricity requirements for the cultivation of micro- and macroalgae, the mariculture of sponges allows the 
continuous growth of the organisms with relatively low input requirements. An additional advantage of in situ cultivation is related to the use of natural resources (e.g. seawater and nutrients in water column) as substitutes of raw materials from previous production processes (e.g. chemicals used to prepare culture media). Nevertheless, the use of chemicals for this purpose can also be avoided in closed systems by feeding the aquariums with natural seawater directly pumped from the coast, as in the scheme presented by Pérez-López et al. (2014a).

Due to the large contribution of the extraction stages in the S. spinosulus process, and particularly the high environmental impact of the production of chemicals used to obtain the crude extract from the harvested sponge biomass, a sensitivity assessment is proposed in this section to evaluate the future steps to be conducted towards the reduction of solvent consumption. Moreover, the life cycle inventory presented in previous sections of the LCA study relies on assumptions and extrapolations from small scale systems that may suffer modifications when implementing in continuous mode. The effect of the most influential assumptions is also considered to define the alternative scenarios analyzed in this section.

\section{* Optimization of solvent consumption}

The production of solvents causes more than $80 \%$ of the environmental burdens associated with the production of prenilyhydroquinones from S. spinosulus. With this regard, several authors have demonstrated the feasibility of solvent recovery and reuse for the extraction of other metabolites from sponges (Blaicher et al., 1981; Harkrader and Jones, 1998).

Therefore, the recovery of solvents used for the preparation of the crude extract is here evaluated. Thus, the individual recovery of $50 \%$ methanol (Sc 2), hexane (Sc 3), chloroform (Sc 4) and carbon tetrachloride (Sc 5) are analyzed. The recovery 
percentage is based on the reuse scenario proposed by Pérez-Lopez et al. (2014a)in a previous study on a bioactive molecule from another sponge. In addition, a combined scenario (Sc 6) based on the reuse of the four solvents is proposed.

According to the results (Figure 4), the recovery of the solvents used in stage S6 would involve remarkable reductions of impact. The most limited effect is observed for the reuse of methanol, with an improvement between $1 \%$ and $5 \%$ in most categories. Hexane recovery may involve impact reductions from $1 \%$ to $10 \%$, except for POFP (21\% reduction).The environmental performance when reducing the consumption of chloroform presents significant reductions ranging from $3 \%$ (for HTP) to $50 \%$ (for ODP). The reuse of carbon tetrachloride also involves important reductions between $9 \%$ and $47 \%$, except for the categories of ODP and LDirect, which are mainly linked (for S6) with the production of chloroform. The combined reuse of the four solvents would allow a global improvement between $37 \%$ and 50\%. Despite the environmental improvement, the relative contributions of S6 still dominate the global profile, with impacts between $55 \%$ and $99 \%$ for the best scenario (Sc 6). 


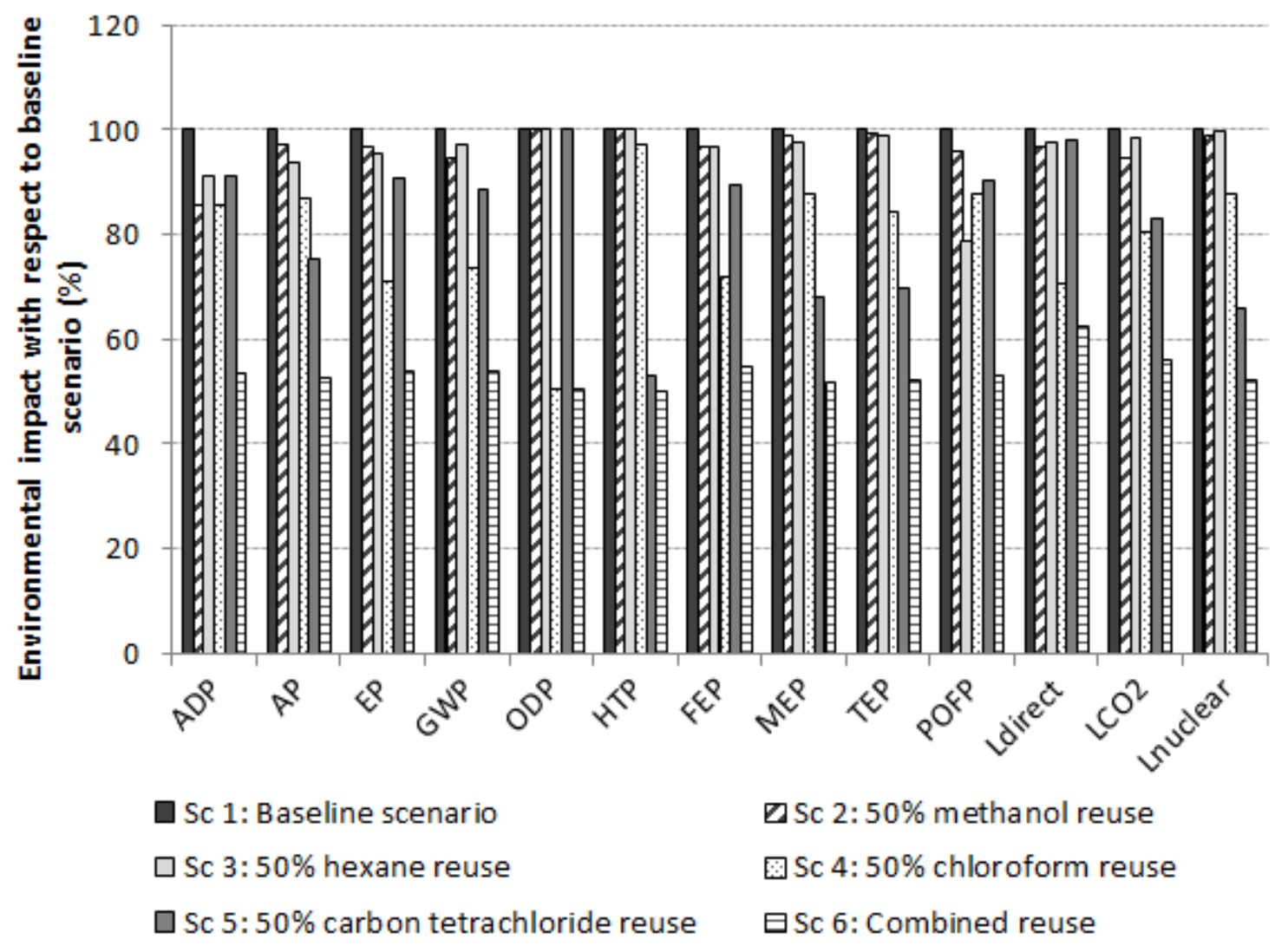

Figure 4.Effect of solvent reuse during the preparation of the crude extract on the environmental profile of the production of prenylhydroquinones by S. spinosulus.

\section{* Effect of vessel operations}

The environmental impacts of the materials required and emissions derived from vessel operation have a secondary contribution below $6 \%$ in all categories when considering the baseline scenario. However, if solvent optimization is applied, the relative contribution of vessel operation may increase significantly, so the effect of the assumptions considered to obtain the life cycle inventory of this subsystem is discussed in this subsection.

The baseline scenario consisted in the use of an inflatable boat for S1 and S2. However, this boat could also be used for other tasks (such as the preparation of mariculture systems in other locations). In this case, the production of the materials for the boat cannot be exclusively allocated to prenylhydroquinone production, but only a fraction 
of them is associated with the process. Sc 7 is proposed to evaluate the effect of the shared use of the boat, assuming an average use of $2 \mathrm{~h}$ per week each year. In addition, the effect of the substitution of the inflatable boat by a polyester fiberglass boat (with more maintenance requirements - painting and antifouling required - but a longer life span) was considered in Sc 8. The same annual sharing conditions of Sc 7 were assumed.

The baseline scenario is based on the assumption that no boat and SCUBA equipment are needed for stages S4 (monitoring) and S5 (sponge harvesting). However, depending on the distance of the mariculture system to the shore, this assumption may be inaccurate. To take into account the possible need for boat and diving in these stages, Sc 9 and Sc 10 are also evaluated. Sc 9 corresponds to a 30 min sailing for each monitoring session (4 sessions per year), a 30 min sailing for the annual harvesting and the corresponding SCUBA equipment, with an exclusive use of the boat for the analyzed process. Sc 10 evaluates the same conditions with a shared boat ( $2 \mathrm{~h}$ of use per week). The results, depicted in Figure 5, show that the assumptions considered to obtain the LCI data associated with the vessel operations have a minor effect on the final results. Sc 7 and Sc 8 have a slightly better performance than the baseline case, with impact reductions between $2 \%$ and $15 \%$ except for ODP and HTP. The impact in the latter categories is nearly the same in Sc 7 and Sc 8 as that of Sc 1 due to the dominance of chemicals for S6 and the subsequent low contribution of vessel operations. Since the improvement is similar for Sc 7 and Sc 8, the changes in the environmental profile for Sc 8 may be linked to the effect of the shared use rather than to the substitution of materials itself. Thus, the results suggest that the higher impacts of a boat with a larger need of materials and chemicals for maintenance are balanced by the benefits of a longer life span of the vessel. 
Furthermore, the use of boat and SCUBA equipment in the monitoring and harvesting stages (S4 and S5) involves a limited increase in the environmental impacts. The worst scenario (Sc 9) has contributions between 2\% and 8\% higher than Sc 1 for categories such as ADP, AP, EP,GWP or LDirect. In other categories with a lower relative contribution of vessel operations, the change has virtually no effect. In the case of Sc 10, some categories such as ADP, FEP, MEP, TEP, LDirect and $\mathrm{LCO}_{2}$ show a slight reduction of impact with respect to the baseline scenario, which is linked to the lower amount of material associated with the process under assessment, due to the shared use of the vessel.

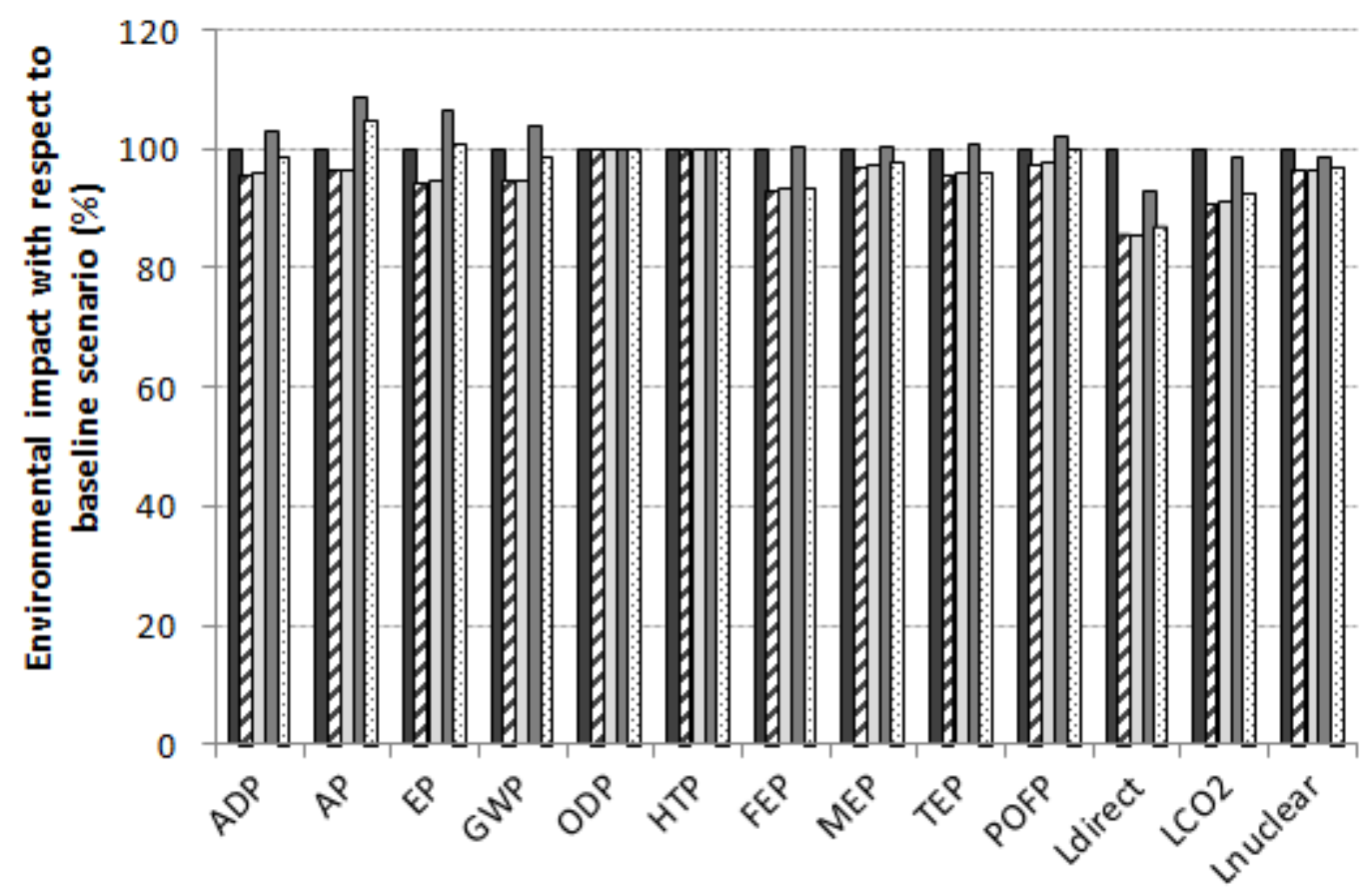

$\square$ Sc 1: Baseline scenario

ZSC 7: Inflatable boat for S1 and S2, shared use $\square$ Sc 8: Polyester boat for S1 and S2, shared use $\square$ Sc 9: $30 \mathrm{~m}$ in boat for $\mathrm{S4}$ and $\mathrm{S5}+$ diving, exclusive use 응 10: 30 min boat for $\$ 4$ and S5 + diving shared use

Figure 5.Effect of assumptions for the LCI of vessel operations on the environmental profile of the production of prenylhydroquinones by S. spinosulus. 
The limited effect of the assumptions considered to obtain the inventory data for the stages involved in the cultivation of sponges in the mariculture system results from the low relative contribution of these stages compared to the downstream processing. In an optimized process with lower requirements for the extraction of compounds, the selection of appropriate procedures for the collection and monitoring of the cultivation system may affect significantly the global environmental profile.

\section{* Effect of changes in survival rates}

In this case, an average survival rate of $80 \%$ was assumed, according to the values reported by Leddaet al. $(2009$; 2014) for mariculturein the Mediterranean Sea. As previously highlighted, a wide range of values for this parameter can be found in the literature, depending on several factors that include the species, location and other surrounding conditions (Duckworth, 2009; Schippers et al., 2012).

In order to evaluate changes in the environmental performance associated with possible variations in the survival rate, a sensitivity assessment is shown in Figure 6. The variations in the growth rate are not evaluated here, since this parameter is interrelated with the survival rate, and thus, the effect would be equivalent. Both parameters are jointly used to calculate the total amount of biomass harvested after one year of growth. 


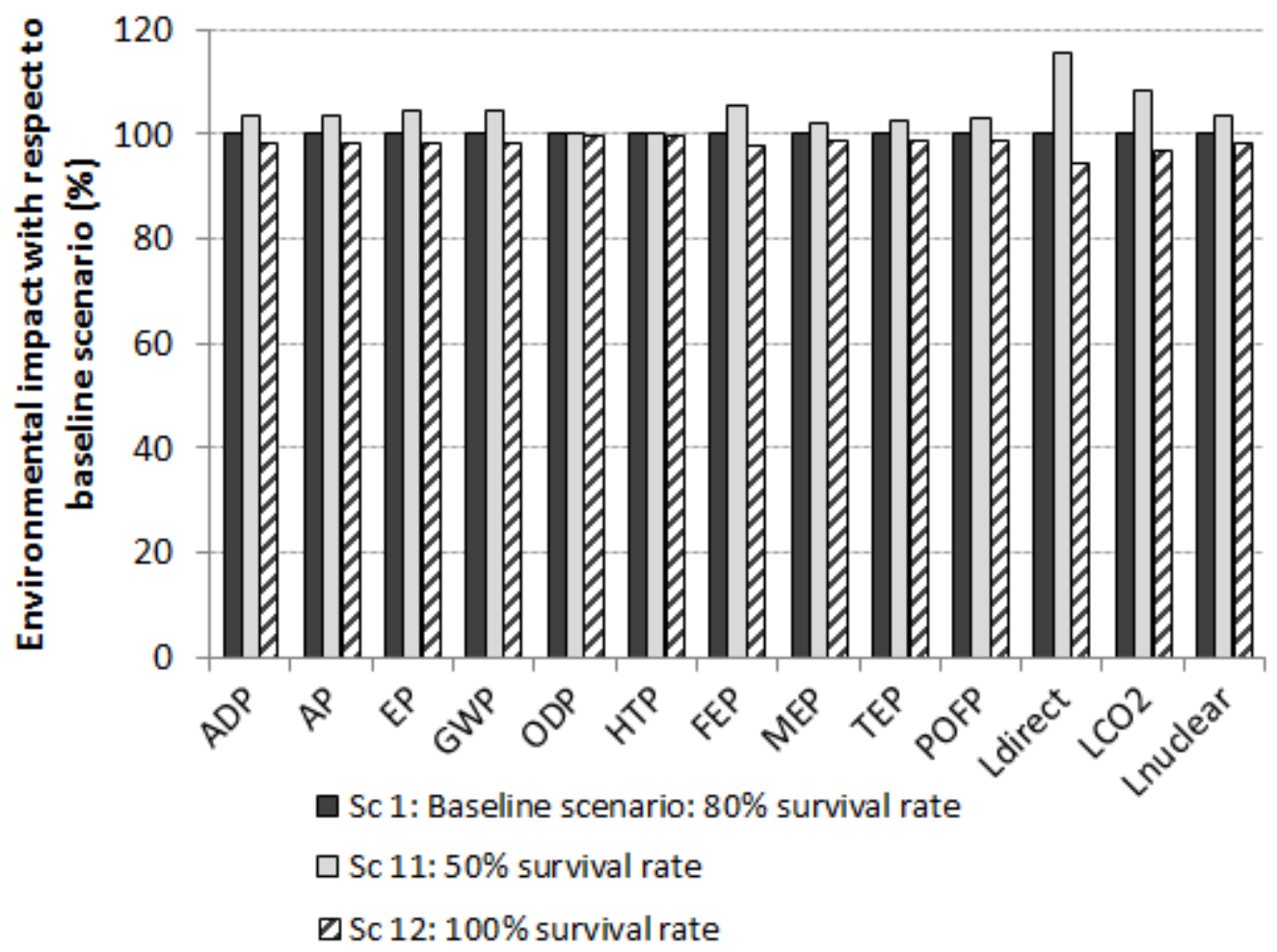

Figure 6Effect of variations in the survival rate on the environmental profile of the production of prenylhydroquinones by $S$. spinosulus.

As in the case of vessel operations, the influence of the survival rate on the environmental impacts of the process is limited due to the low relative contributions of the mariculture stages compared to the downstream processing stages. Thus, the increase of the contributions to CML impact categories due to a lower survival rate (50\%) does not exceed $6 \%$, whereas the improvement is below $2 \%$ for the maximum survival rate $(100 \%)$. As expected, the lowest changes correspond to the categories of ODP and HTP, in which more than $99 \%$ of the impact is associated with the production of solvents. The most significant difference is associated with land occupation categories, in particular LDirect and $\mathrm{LCO}_{2}$. Thus, a 50\% survival rate would lead to an increase of $16 \%$ in LDirect and $8 \%$ in $\mathrm{LCO}_{2}$, whereas the maximum survival rate would involve impact reductions of 5\% and 3\%, respectively. These results are mainly due to 
the remarkable contribution of vessel operations to land occupation (11\% to LDirect and $5 \%$ to $\mathrm{LCO}_{2}$ in the baseline scenario).

\section{* Bioremediation potential}

The filtering capacity of the sponges was found to be rather limited compared to the total environmental impact of the system. These results are mainly due to the large amount of solvents required for the extraction stages. Despite the limited energy saving in the analyzed farming plant related to the reduction of bacterial concentration, its combination in integrated aquaculture systems may represent an attractive economic and environmental solution. For example, the pollution caused by floating cages for fish breeding can be reduced by coupling this productive activity to the installation of a sponge farming system (Manconi et al., 1999).

\section{Conclusions}

This work provides the first detailed life cycle inventory and environmental assessment for the in situ production of sponge biomass (in particular, S. spinosulus) and further extraction stages to obtain a biologically active fraction: prenylhydroquinones.

The conducted assessment highlights the importance of solvent extraction (responsible for more than $80 \%$ of the environmental impact for all the analyzed categories) and the remarkable optimization potential, which led to impact reductions between $1 \%$ and $50 \%$ with reference to the baseline scenario. Moreover, this LCA demonstrates the validity of the assumptions in the inventory stage. Thus, changes in the analyzed key parameters (i.e. different conditions for the use of boats in the monitoring of growth and survival rates) result in limited variations (below $10 \%$ in all cases) of the obtained environmental profile with respect to the baseline scenario. 
Moreover, the results suggest thatthe mariculture of sponges allows the continuous growth of the organisms with relatively low input requirements. This advantage is related to the use of natural resources (e.g. seawater and nutrients in water column) as substitutes of raw materials from previous production processes (e.g. chemicals used to prepare artificial culture media). 
AcknowledgementsThis research was financially supported by BAMMBO Project Sustainable Production of Biologically Active Molecules of Marine Based Origin. (Project reference: FP7 KBBE-2010-4 - 265896). The authors from the University of Santiago de Compostela belong to CRETUS (AGRUP 2015/02) and the Galician Competitive Research Group GRC 2013-032, program co-funded by FEDER. P. PérezLópez would like to thank the Spanish Ministry of Education for awarding a research scholarship (AP2012-1605).F.D. Ledda was supported by grants from Regione Autonoma della Sardegna (RAS 'Promozione della Ricerca scientifica e dell'innovazione tecnologica in Sardegna', PO/FSE/Sardegna2007/13, L.R.7/2007, CRP1_324) and by Università di Genova and Università di Sassari. E.Perino was supported by grants from Università di Genova.

\section{References}

Abed, C., Legrave, N., Dufies, M., Robert, G., Guérineau, V., Vacelet, J., Auberger, P., Amade, P., Mehiri, M., 2011.A new hydroxylated nonaprenylhydroquinone from the Mediterranean marine sponge Sarcotragusspinosulus. Marine Drugs 9, 12101219.

Aitken, D., Bulboa, C., Godoy-Faundez, A., Turrion-Gomez, J.L., Antizar-Ladislao, B., 2014.Life cycle assessment of macroalgae cultivation and processing for biofuel production. Journal of Cleaner Production 75, 45-56.

Althaus HJ, Chudacoff M, Hischier R, Jungbluth N, Osses M, Primas A. Life cycle inventories of chemicals. Ecoinvent report No. 8, v2.0. EMPA, Swiss Centre for Life Cycle Inventories,Dübendorf (Switzerland); 2007.

Beedessee, G., Ramanjooloo, A., Marie, D.E.P., 2015. Marine natural products research in Mauritius: Progress and challenges. Marine Chemistry 170, 23-28. 
Bergman, O., Mayzel, B., Anderson, M.A., Shpigel, M., Hill, R.T., Ilan, M., 2011.Examination of marine-based cultivation of three demosponges for acquiring bioactive marine natural products. Marine Drugs 9, 2201-2219.

Bergquist, P., 1978. Sponges. Hutchinson and Company, London (UK).

Bisio, A., Fedele, E., Pittaluga, A., Olivero, G., Grilli, M., Chen, J., Mele, G., Malafronte, N., De Tommasi, N., Ledda, F., Manconi, R., R, P., Marchi, M., 2014. Isolation of hydroxyoctaprenyl-1',4'-hydroquinone, a new octaprenylhydroquinone from the marine sponge Sarcotragusspinosulus, and evaluation of its pharmacological activity on acetylcholine and glutamate release in the rat central nervous system. Natural Product Communications 9, 15811584.

Blaicher, F.M., Nolte, R., Mukherjee, K.D., 1981. Lupin protein concentrates by extraction with aqueous alcohols. J Am Oil ChemSoc 58, A761-A765.

Blunt, J.W., Copp, B.R., Keyzers, R.A., Munro, M.H.G., Prinsep, M.R., 2015. Marine natural products. Natural Product Reports 32, 116-211.

Bondu, S., Genta-Jouve, G., Leirós, M., Vale, C., Guigonis, J.-M., Botana, L.M., Thomas, O.P., 2012. Additional bioactive guanidine alkaloids from the Mediterranean sponge Crambecrambe. RSC Advances 2, 2828-2835.

Brentner, L.B., Eckelman, M.J., Zimmerman, J.B., 2011. Combinatorial Life Cycle Assessment to inform process design of industrial production of algal biodiesel. Environmental Science \&Technology 45, 7060-7067.

Cimino, G., de Stefano, S., Minale, L., 1972. Polyprenyl derivatives from the sponge Irciniaspinosula: 2-polyprenylbenzoquinones, 2-polyprenylbenzoquinols, prenylated furans and a C-31 difuranoterpene. Tetrahedron 28(5), 1315-1324. 
Classen M, Althaus HJ, Blaser S, Tuchschmid M, Jungbluth N, Doka G, et al. Life cycle inventories of metals. Ecoinvent report No. 10, v2.0. EMPA, Swiss Centre for Life Cycle Inventories,Dübendorf (Switzerland), 2007.

Collet, P., Hélias, A., Lardon, L., Ras, M., Goy, R.A., Steyer, J.-P., 2011. Life-cycle assessment of microalgae culture coupled to biogas production. BioresourceTechnology 102, 207-214.

De Caralt, S., Sánchez-Fontenla, J., Uriz, M.J., Wijffels, R.H., 2010. In situ aquaculture methods for Dysideaavara (Demospongiae, Porifera) in the Northwestern Mediterranean.Marine Drugs 8, 1731.

Doka G. Life cycle inventories of waste treatment services. Ecoinvent report No. 13, v2.0. EMPA, Swiss Centre for Life Cycle Inventories, Dübendorf (Switzerland); 2007.

Dones R, Bauer C, Bolliger R, Burger B, FaistEmmenegger M, Frischknecht R, et al. Life cycle inventories of energy systems: Results for current systems in Switzerland and other UCTE countries. Ecoinvent report No. 5, v2.0. Paul ScherrerInstitutVilligen, Swiss Centre for Life Cycle Inventories, Dübendorf (Switzerland); 2007.

Duckworth, A., 2009. Farming sponges to supply bioactive metabolites and bath sponges: A review. Mar Biotechnol 11, 669-679.

Dybdal-Hargreaves, N.F., Risinger, A.L., Mooberry, S.L., 2015.Eribulinmesylate: Mechanisms of action of a unique microtubule-targeting agent. Clinical Cancer Research 21, 2445-2452.

EMEP/EEA, 2009.EMEP/EEA air pollutant emission inventory guidebook - 2009. European Environment Agency, Copenhagen (Denmark). 
European Commission, 2003.Communication from the Commission to the Council and the European Parliament. Integrated Product Policy - Building on Environmental Life-Cycle Thinking,COM(2003) 302 final, Brussels.

European Commission, Joint Research Centre, 2012. Characterisation factors of the ILCD Recommended Life Cycle Impact Assessment methods. Database and supporting information. First edition, in: Union, P.O.o.t.E. (Ed.), Luxembourg.

Gerrodette, T., Flechsing, A.O., 1979.Sediment-induced reduction in the pumping rate of the tropical sponge Verongialacunosa.Marine Biology 55.

Goedkoop, M.J., Heijungs, R., Huijbregts, M., De Schryver, A., Struijs, J., Van Zelm, R., 2013a.ReCiPe 2008, A life cycle impact assessment method which comprises harmonised category indicators at the midpoint and the endpoint level. First edition (version 1.08). Report I: Characterisation.

Goedkoop, M., Oele, M., Leijting, J., Ponsioen, T., Meijer, E., 2013b.SimaPro 8.Introduction to LCA with SimaPro.PréConsultants.

Guinée, J.B., Gorrée, M., Heijungs, R., Huppes, G., Kleijn, R., de Koning, A., van Oers, L., Wegener, A., Suh, S., Udo de Haes, H.A., de Bruijn, H., van Duin, R., 2002. Handbook on life cycle assessment: Operational guide to the ISO standards. Kluwer Academic Publishers, Dordrecht (The Netherlands).

Harkrader, R.D., Jones, R.R., 1998. Purificaion of benzophenanthridine alkaloids extracts from alkaloid extracts. Atrix Laboratories, Inc, United States.

Hischier R. Life cycle inventories of packagings and graphical papers. Ecoinvent report No. 11, v2.0. EMPA, Swiss Centre for Life Cycle Inventories, Dübendorf (Switzerland); 2007.

Hischier R, Classen M, Lehmann M, Scharnhorst W. Life cycle inventories of electric and electronic equipment: production, use and disposal. Ecoinvent report No. 18, 
v2.0. EMPA, Swiss Centre for Life Cycle Inventories,Dübendorf (Switzerland); 2007.

Hospido, A., Tyedmers, P., 2005. Life cycle environmental impacts of Spanish tuna fisheries. Fisheries Research 76, 174-186.

Huijbregts, M.A.J., Hellweg, R., Frischknecht, R., Hungerbühler, K., Hendriks, A.J., 2008. Ecological footprint accounting in the life cycle assessment of products. Ecological Economics 64(4):798-807.

Huyck, T.K., Gradishar, W., Manuguid, F., Kirkpatrick, P., 2011.Eribulinmesylate. Nature Reviews Drug Discovery 10, 173-174.

ISO 14040, 2006.Environmental Management - Life Cycle Assessment - Principles and Framework, Geneva, Switzerland.

Jungbluth N. Erdöl. In: Sachbilanzen von Energiesystemen: Grundlagenfür den ökologischenVergleich von Energiesystemen und den Einbezug von Energiesystemen in Ökobilanzenfür die Schweiz. Ecoinvent report No. 6-IV, v2.0. Paul ScherrerInstitutVilligen, Swiss Centre for Life Cycle Inventories,Dübendorf (Switzerland); 2007.

Kulchin, Y.N., Bezverbny, A.V., Bukin, O.A., Voznesensky, S.S., Galkina, A.N., Drozdov, A.L., Nagorny, I.G., 2009. Optical and nonlinear optical properties of sea glass sponge spicules, in: Müller, W.E.G., Grachev, M.A. (Eds.), Biosilica in Evolution, Morphogenesis, and Nanobiotechnology. Springer Berlin Heidelberg, pp. 315-340.

Langlois, J., Hélias, A., Delgenès, J., Steyer, J.-P., 2012. Life cycle assessment of biomethane from offshore-cultivated seaweed. Biofuels, Bioproducts and Biorefining 6, 387-404. 
Lardon, L., Hélias, A., Sialve, B., Steyer, J.-P., Bernard, O., 2009.Life-cycle assessment of biodiesel production from microalgae.EnvironmentalScience\&Technology $43,6475-6481$.

Ledda, F.D., 2009. Valorizzazione e sfruttamentorazionaledeiporiferi: spongicoltura per la produzione di biomassa e biorimediazione. $\mathrm{PhD}$ Thesis. Genoa University, pp. 146.

Ledda, F.D., Pronzato, R., Manconi, R., 2014. Mariculture for bacterial and organic waste removal: a field study of sponge filtering activity in experimental farming. Aquaculture Research 45, 1389-1401.

Ling, T., Poupon, E., Rueden, E.J., Kim, S.H., Theodorakis, E.A., 2002. Unified synthesis of quinonesesquiterpenes based on a radical decarboxylation and quinone addition reaction. Journal of the American Chemical Society 124, $12261-12267$.

Manconi, R., Cubeddu, T., Corriero, G., Pronzato, R., 1999.Commercial sponges farming as a natural control of floating cages pollution, in: Enne, G.a.G., G.F (Ed.), New species for Mediterranean aquaculture. BiofuturElsevier, pp. 269274.

Mercurio, M., Corriero, G., Gherardi, M., Baldacconi, R., Gaino, E., 2013. Sexual reproduction in Sarcotragus spinosulus from two different shallow environments. Marine Ecology 34, 394-408.

Molinari, A., Oliva, A., Aguilera, N., Miguel del Corral, J.M., Castro, M.A., Gordaliza, M., García-Grávalos, M.D., San Feliciano, A., 2000. New antineoplastic prenylhydroquinones. Synthesis and evaluation. Bioorganic \& Medicinal Chemistry 8, 1027-1032. 
Murray, P.M., Moane, S., Collins, C., Beletskaya, T., Thomas, O.P., Duarte, A.W.F., Nobre, F.S., Owoyemi, I.O., Pagnocca, F.C., Sette, L.D., McHugh, E., Causse, E., Pérez-López, P., Feijoo, G., Moreira, M.T., Rubiolo, J., Leirós, M., Botana, L.M., Pinteus, S., Alves, C., Horta, A., Pedrosa, R., Jeffryes, C., Agathos, S.N., Allewaert, C., Verween, A., Vyverman, W., Laptev, I., Sineoky, S., Bisio, A., Manconi, R., Ledda, F., Marchi, M., Pronzato, R., Walsh, D.J., 2013. Sustainable production of biologically active molecules of marine based origin. New Biotechnology 30, 839-850.

Newman, D.J., Cragg, G.M., 2004. Marine natural products and related compounds in clinical and advanced preclinical trials. Journal of Natural Products 67, 12161238.

Osinga, R., Sidri, M., Cerig, E., Gokalp, S.Z., Gokalp, M., 2010. Sponge aquaculture trials in the East-Mediterranean Sea: New approaches to earlier ideas. The Open Marine Biology Journal 4, 74-81.

Page, M.J., Handley, S.J., Northcote, P.T., Cairney, D., Willan, R.C., 2011.Successes and pitfalls of the aquaculture of the sponge Mycale hentscheli. Aquaculture $312,52-61$.

Page, M.J., Northcote, P.T., Webb, V.L., Mackey, S., Handley, S.J., 2005. Aquaculture trials for the production of biologically active metabolites in the New Zealand sponge Mycale hentscheli (Demospongiae: Poecilosclerida). Aquaculture 250, 256-269.

Pérez-López, P., Ternon, E., González-García, S., Genta-Jouve, G., Feijoo, G., Thomas, O.P., Moreira, M.T., 2014a. Environmental solutions for the sustainable production of bioactive natural products from the marine sponge Crambecrambe. Science of the Total Environment 475, 71-82. 
Pérez-López, P., González-García, S., Jeffryes, C., Agathos, S.N., McHugh, E., Walsh, D.J., Murray, P., Moane, S., Feijoo, G., Moreira, M.T., 2014b. Life cycle assessment of the production of the red antioxidant carotenoid astaxanthin by microalgae: from lab to pilot scale. Journal of Cleaner Production 64, 332-344.

Pérez-López, P., Jeffryes, C., Agathos, S.N., Feijoo, G., Rorrer, G., Moreira, M.T., 2016. Environmental life cycle optimization of essential terpene oils produced by the macroalgaOchtodessecundiramea. Science of The Total Environment 542, Part A, 292-305.

Pronzato, R., Manconi, R., 2008. Mediterranean commercial sponges: over 5000 years of natural history and cultural heritage. Marine Ecology 29, 146-166.

Ran, N., Knop, D.R., Draths, K.M., Frost, J.W., 2001.Benzene-free synthesis of hydroquinone. Journal of the American Chemical Society 123, 10927-10934.

Schippers, K.J., Sipkema, D., Osinga, R., Smidt, H., Pomponi, S.A., Martens, D.E., Wijffels, R.H., 2012. Cultivation of sponges, sponge cells and symbionts: Achievements and future prospects, in: Becerro, M.A., Uriz, M.J., Maldonado, M., Turon, X. (Eds.), Advances in Marine Biology. Academic Press, pp. 273337.

Sipkema, D., Franssen, M.R., Osinga, R., Tramper, J., Wijffels, R., 2005a. Marine sponges as pharmacy.Mar Biotechnol 7, 142-162.

Sipkema, D., Osinga, R., Schatton, W., Mendola, D., Tramper, J., Wijffels, R.H., 2005b. Large-scale production of pharmaceuticals by marine sponges: Sea, cell, or synthesis? Biotechnology and Bioengineering 90, 201-222.

Stabili, L., Licciano, M., Giangrande, A., Longo, C., Mercurio, M., Marzano, C.N., Corriero, G., 2006. Filtering activity of Spongia officinalis var. 
adriatica(Schmidt) (Porifera, Demospongiae) on bacterioplankton: Implications for bioremediation of polluted seawater.Water Research 40, 3083-3090.

Steiner R, Frischknecht R. Metals processing and compressed air supply. Ecoinvent report No. 23, v2.0. Swiss Centre for Life Cycle Inventories, Dübendorf (Switzerland); 2007.

Taelman, S.E., Champenois, J., Edwards, M.D., De Meester, S., Dewulf, J., 2015. Comparative environmental life cycle assessment of two seaweed cultivation systems in North West Europe with a focus on quantifying sea surface occupation. Algal Research 11, 173-183.

Thakur, N.L., Müller, W.E.G., 2004. Biotechnological potential of marine sponges. Current Science 86, 1506-1512.

Vázquez-Rowe, I., Moreira, M.T., Feijoo, G., 2010. Life cycle assessment of horse mackerel fisheries in Galicia (NW Spain): Comparative analysis of two major fishing methods. Fisheries Research 106, 517-527.

Von Blottnitz, H., Curran, M.A., 2007. A review of assessments conducted on bioethanol as a transportation fuel from a net energy, greenhouse gas, and environmental life cycle perspective. Journal of Cleaner Production 15, 607-619.

Ziegler, F., Hornborg, S., Green, B.S., Eigaard, O.R., Farmery, A.K., Hammar, L., Hartmann, K., Molander, S., Parker, R.W.R., Hognes, E.S., Vázquez-Rowe, I., Smith, A.D.M, 2016. Expanding the concept of sustainable seafood using Life Cycle Assessment. Fish and Fisheries 17(4):1073-1093. 